\title{
Physical therapy management of an elite rock climber with subacromial impingement syndrome (SIS)
}

\author{
Court Zollinger, Alex Urfer* and Derek Gerber
}

*Correspondence: urfealex@isu.edu

\author{
CrossMark
}

$\leftarrow$ Click for updates

Idaho State University, Department of Physical and Occupational Therapy, Pocatello, Idaho 83209 USA.

\begin{abstract}
Background: The purpose of this case report is to describe a conservative physical therapy plan that was successful in the treatment of a functional classification of subacromial impingement syndrome (SIS). SIS is a common shoulder diagnosis and accounts for approximately $44-65 \%$ of shoulder cases presented in primary care [1]. Impingement syndrome can be classified into either a functional or structural categorization, determined by the causative factor, and is frequently seen with repetitive overhead activities [1,2].

Case Description: The patient was a 29 -year-old elite female rock climber who presented to our clinic after an extended overseas climbing trip. The patient injured her left shoulder twice during the trip with both injuries occurring while her shoulder was in a flexed and internally rotated position. The patient reported that her painful symptoms resolved after the initial injury with the use of self-treatment with therapeutic exercises found online and performed while on the expedition. Six months later, the patient reinjured her shoulder with the same mechanism of injury. The patient presented to the clinic with signs and symptoms suggesting impingement within the glenohumeral joint.

Discussion/Outcome: After six weeks of manual therapy, therapeutic exercise, and a detailed home exercise program, the patient returned to her normal climbing activities symptom free. Significant gains in range of motion $(\mathrm{ROM})$ of the glenohumeral joint and strength of shoulder musculature and scapular stabilizers were noted through clinical testing and her pain was completely resolved. At discharge, all clinical special tests for impingement were negative and her Quick Disabilities of Arm, Shoulder, and Hand (QDASH) score decreased from 18 to 5.

Conclusion: Through an extensive literature search performed to guide treatments, it was found that a focus on manual therapy techniques was extremely beneficial for a patient diagnosed with SIS. The use of manual therapy as the cornerstone for treatment sessions supplemented with ROM and strengthening activities allowed the patient to return to her previous functional status and rock climbing symptom-free. This case report parallels the current evidence that conservative treatment may be efficacious in the treatment of SIS when the etiology is secondary to a functional classification.
\end{abstract}

Keywords: Subacromial impingement syndrome, manual therapy, physical therapy

\section{Background}

Subacromial impingement syndrome (SIS) is a common diagnosis presenting to primary care physicians with an incidence of approximately $44-65 \%$ of the population [1]. SIS is more commonly experienced by males than females, more prevalent in patients who are 40 years of age or older and is commonly seen in individuals who participate in overhead activities [3]. SIS primarily manifests with pain unilaterally on the patient's 
dominant side. This pain is commonly localized to the superior and lateral aspect of the involved shoulder, and results in increased pain with abduction and internal rotation, decreased range of motion (ROM) around the involved glenohumeral joint, scapular dyskinesis, and potential edema and erythema of the involved extremity [1].

There are two primary categorizations for SIS: structural and functional. Both of these classifications lead to decreased subacromial space on the involved upper extremity. In a healthy shoulder, the normal range of space between the superior aspect of the humeral head and the inferior aspect of the acromion is approximately 6-14 millimeters [4]. SIS is categorized as structural when there is a narrowing of the subacromial space caused by a bony growth, i.e. an osteophyte, or the inflammation of soft tissues located within the subacromial space [2]. A structural classification of SIS may require a surgical procedure to ameliorate the causative factor(s) [2]. A functional classification of SIS focuses on the mechanical cause(s) of subacromial space narrowing as opposed to an anatomic anomaly [2]. According to Page, functional classification is related to glenohumeral instability allowing increased translation of the humeral head secondary to existing muscular imbalances [2]. In literature, a functional classification of SIS is commonly seen with increased electromyography (EMG) activity in the upper trapezius muscle with decreased EMG activity in the middle and lower trapezius and serratus anterior muscles [2]. As the se mechanical causative factors are primarily muscle force couple imbalances, SIS diagnosed as a functional classification is amenable to physical therapy treatment and typically has a successful resolution of symptoms in $60-90 \%$ of cases, whether the symptoms be correcting the muscle force couple imbalances, increasing muscle strength or glenohumeral ROM, or simply decreasing pain $[2,3]$.

A clinical diagnosis of SIS is often formed from the patient's subjective complaints and through positive clinical special tests and findings. There are several special tests that can assist ruling SIS in or out. These tests include, but are not limited to, Neer, Hawkins-Kennedy, drop arm, painful arc of motion, and the infraspinatus muscle test $[1,5]$. Clusters of tests are commonly employed to rule in or out conditions as individual special tests may not have high sensitivity and specificity when used as stand alone tests. One such cluster for SIS involves performing the Hawkins-Kennedy, painful arc of motion, and infraspinatus muscle test [5]. With positive results on all three tests, the likelihood ratio of being able to rule in SIS as a potential pathology increases to 10.56 [5]. When using the Hawkins-Kennedy test alone, a key special test in the diagnosis of SIS, the likelihood ratio is a mere 1.35, thus supporting the use of the test cluster $[5, \mathbf{6}]$.

As previously noted, a patient who is diagnosed with a structural classification of SIS may opt for a surgical procedure to correct the anatomical anomalies. The primary surgical procedure performed is the subacromial decompression. In this procedure, the surgeon will debride the underside of the acromion with the goal of increasing the subacromial space [7]. According to Page, conservative care and treatment for a functional classification of SIS focuses primarily on the underlying cause of the altered arthrokinematics rather than symptomatic treatment alone [2].

The aim of this case report is to detail and outline a conservative intervention physical therapy plan of care that was successful in treating the symptoms of functional SIS and facilitate a return of full rock climbing activity. The concepts of this physical therapy plan, such as manual therapy and correcting muscle force couple imbalances, may be beneficial for the treatment of a functional classification of SIS.

\section{Case presentation}

\section{Subjective examination}

The patient was an active and healthy 29-year-old female professional rock climber who presented to the clinic with primary complaints of left shoulder pain and inability to rock climb without experiencing pain. This patient was selected to perform a case report on secondary to her interesting history along with the amount of activity she participated in, which regularly included stressing her involved upper extremity and frequenting upper extremity closed chain positions. Written consent was obtained from the patient to participate in this case report. The patient injured her shoulder, twice, while on a year-long rock climbing expedition throughout Europe and Asia. Both incidents occurred when the patient was performing "crack" climbing with her upper extremity in a flexed and internally rotated position while wedging her hands and fingers into vertical and horizontal cracks to gain purchase to ascend the rock, thus suffering from the same mechanism of injury for both injuries. After the initial injury, the patient found physical therapy exercises online and utilized resistance band/tubing with self-selected exercises for 3 months, leading to a resolution of her symptoms. Six months later while crack climbing in China, the patient reported the same pain as the prior injury but waited to seek medical attention until she returned to the United States. The patient was referred to the physical therapy clinic by her general practitioner. The patient opted to partake in conservative treatment prior to any medical imaging or other treatment options. The patient presented with a limited past medical history that included a patient reported $L 6$ fracture as well as a calcaneal fracture. Both of these injuries were resolved and were not expected to have an impact on the treatment for the current injury of SIS. The patient generated goals were to achieve a strong and balanced shoulder, and to return to rock climbing activities.

\section{Physical examination}

The examination of the patient revealed clear deficits during observation and clinical testing which included decreased strength, glenohumeral range of motion, and pain with certain positions assumed during diagnostic clinical special tests. Through initial screening, cervical pathology, neural 
involvement, and systemic causes of the left upper extremity pain were ruled out. The patient demonstrated severe bilateral scapular dyskinesia and a decrease in active range of motion (AROM) of the involved left shoulder when compared to the non-involved right shoulder via observation. Shoulder AROM measurements, both at evaluation and discharge, are included in Table 1. Passive range of motion (PROM) and joint play assessment were used to rule out intraarticular pathology. During PROM of the left shoulder, the patient became apprehensive with flexion at $150-155^{\circ}$, signifying an empty end feel. For PROM measurements, refer to Table 2. Four clinical special tests performed were positive for SIS, while additional tests for capsular and other soft tissue involvement were negative. For a complete list of special tests and results, at evaluation and discharge, please refer to Table 3.

Table 1. Active Range of Motion Measurements.

\begin{tabular}{lllll}
\hline Position & Right & \multicolumn{3}{l}{ Left } \\
\cline { 2 - 5 } & Evaluation & Discharge & Evaluation & Discharge \\
\hline Flexion & $0-152^{\circ}$ & $0-156^{\circ}$ & $0-151^{\circ}$ & $0-146^{\circ *}$ \\
Abduction & $0-170^{\circ}$ & $0-166^{\circ *}$ & $0-141^{\circ}$ & $0-171^{\circ}$ \\
Internal Rotation & $0-45^{\circ}$ & $0-50^{\circ}$ & $0-50^{\circ}$ & $0-48^{\circ *}$ \\
External Rotation & $0-80^{\circ}$ & $0-90^{\circ}$ & $0-61^{\circ}$ & $0-92^{\circ}$ \\
\hline
\end{tabular}

* Likely secondary to standard error of measurement via goniometry

Table 2. Passive Range of Motion Measurements.

\begin{tabular}{lllll}
\hline \multirow{2}{*}{ Motion Tested } & \multicolumn{2}{l}{ Right Upper Extremity } & \multicolumn{2}{l}{ Left Upper Extremity } \\
\cline { 2 - 5 } & Pre & Post & Pre & Post \\
\hline Flexion & $0-151^{\circ}$ & $0-156^{\circ}$ & $0-150^{\circ}$ & $0-153^{\circ}$ \\
Abduction & $0-180^{\circ}$ & $0-180^{\circ}$ & $0-180^{\circ}$ & $0-179^{\circ}$ \\
External Rotation at $90^{\circ}$ & $0-90^{\circ}$ & $0-100^{\circ}$ & $0-88^{\circ}$ & $0-103^{\circ}$ \\
Internal Rotation at $90^{\circ}$ & $0-45^{\circ}$ & $0-55^{\circ}$ & $0-50^{\circ}$ & $0-55^{\circ}$ \\
\hline
\end{tabular}

Table 3. Clinical Special Tests and Results.

\begin{tabular}{lll}
\hline Special Test & \multicolumn{2}{c}{ Result } \\
\cline { 2 - 3 } & Evaluation & Discharge \\
\hline Hawkins-Kennedy & Positive & Negative \\
Neer Impingement & Positive & Negative \\
Active Compression & Positive & Negative \\
Drop Arm & Negative & Negative \\
Empty Can & Negative & Negative \\
Horizontal Adduction & Positive & Negative \\
Full Can & Negative & Negative \\
Lift Off & Decreased performance & Negative \\
Crank & Negative & Negative \\
\hline
\end{tabular}

Finally, results of manual muscle testing revealed significant imbalances between ipsilateral muscles tested, primarily the scapular stabilizers. According to Page, muscular imbalances are one of the main etiologies of a functional classification of SIS [2]. A complete list of muscles tested, and results, can be found in Table 4 and statistical information related to all examination objective scales and tests and measures are found in Tables 5 and 6.

Table 4. Manual Muscle Testing Results.

\begin{tabular}{|c|c|c|c|c|}
\hline \multirow[t]{2}{*}{ Motion } & \multicolumn{2}{|c|}{ Right Upper Extremity } & \multicolumn{2}{|c|}{ Left Upper Extremity } \\
\hline & Evaluation & Discharge & Evaluation & Discharge \\
\hline Shoulder Flexion & 5 & 5 & 5 & 5 \\
\hline Shoulder Abduction & 5 & 5 & 5 & 5 \\
\hline $\begin{array}{l}\text { Shoulder Internal } \\
\text { Rotation }\end{array}$ & 5 & 5 & 5 & 5 \\
\hline $\begin{array}{l}\text { Shoulder External } \\
\text { Rotation }\end{array}$ & 5 & 5 & 3 & 5 \\
\hline Elbow Flexion & 5 & 5 & 5 & 5 \\
\hline Upper Trap & 5 & $\mathrm{NT}^{*}$ & 5 & $\mathrm{NT}^{*}$ \\
\hline Middle Trap & 5 & 5 & 4 & 5 \\
\hline Lower Trap & $3+$ & 5 & $3+$ & 5 \\
\hline Rhomboids & 3 & 5 & 2 & 5 \\
\hline Serratus Anterior & 5 & 5 & 5 & 5 \\
\hline
\end{tabular}

Table 5. Tests and Measures Validity and Reliability.

\begin{tabular}{|c|c|c|c|}
\hline $\begin{array}{l}\text { Test or } \\
\text { Measurement }\end{array}$ & Validity & Reliability & $\begin{array}{l}\text { Clinically Significant } \\
\text { Difference }\end{array}$ \\
\hline Goniometry $^{15}$ & * & UE: .86 & UE: $5^{\circ} \quad$ LE: $6^{\circ}$ \\
\hline $\begin{array}{l}\text { Manual Muscle } \\
\text { Test }^{16}\end{array}$ & $62.9-72.3 \%$ & $\begin{array}{l}89-92 \% \text { within one } \\
\text { grade, inter-tester }\end{array}$ & NA \\
\hline $\mathrm{QDASH}^{13}$ & .55 & $.91-.96$ & NA \\
\hline
\end{tabular}

* According to Gajdosik and Bohannon, if the measurements are being interpreted the way they are meant to be, as range of motion present around a joint, then goniometry is a valid measurement.

Table 6. Clinical Tests Performed: Statistical Data.

\begin{tabular}{|c|c|c|c|c|}
\hline Special Test & $\begin{array}{l}\text { Positive } \\
\text { Likelihood } \\
\text { Ratio }\end{array}$ & $\begin{array}{l}\text { Negative } \\
\text { Likelihood } \\
\text { Ratio }\end{array}$ & $\begin{array}{l}\text { Sensitivity } \\
\text { Percent }\end{array}$ & $\begin{array}{l}\text { Specificity } \\
\text { Percent }\end{array}$ \\
\hline Hawkins-Kennedy ${ }^{6}$ & 2.12 & .43 & 71.5 & 66.3 \\
\hline Neer Impingement ${ }^{6}$ & 2.19 & .47 & 68 & 68.7 \\
\hline Crank Test ${ }^{17}$ & $.2-1.6$ & $1.0-1.3$ & 9 & 83 \\
\hline $\begin{array}{l}\text { Horizontal } \\
\text { Adduction }^{6}\end{array}$ & 1.25 & .95 & 22.5 & 82 \\
\hline Active Compression ${ }^{17}$ & $.9-1.7$ & $.5-1.2$ & 65 & 49 \\
\hline Lift Off ${ }^{6}$ & $.95-2.44$ & $.54-1.11$ & 46 & 69 \\
\hline Drop Arm Sign ${ }^{6}$ & 2.32 & .83 & 26.9 & 88.4 \\
\hline Empty Can ${ }^{6}$ & $.95-1.76$ & $.32-.96$ & 78 & 40 \\
\hline Full Can ${ }^{6}$ & $1.11-2.31$ & $.24-.66$ & 80 & 50 \\
\hline
\end{tabular}

\section{Evaluation and physical therapy diagnosis}

The results of the examination supported and agreed with the diagnosis of SIS received from the patient's general practitioner. Motions that caused a narrowing of the subacromial space, 
on the involved upper extremity, led to an exacerbation of symptoms. Additionally, the patient displayed posterior glenohumeral capsular tightness, which led to decreased joint motion and improper joint arthrokinematics. The prognosis for a full recovery for this patient was excellent, given her health and activity level, and recovery was expected to be seen after approximately 8-12 weeksof conservative physical therapy intervention, via the literature [1].

\section{Intervention}

The patient was seen twice a week for a six-week duration for a total of twelve sessions with goals of increasing ROM, improving arthrokinematics of the glenohumeral joint, the rotational and translational osteokinematics of the scapulothoracic interface, decreasing capsular tightness, and progressing to full and pain free shoulder ROM. Interventions focused primarily on manual therapy and therapeutic exercise to obtain these goals. Table 7 depicts the precise daily intervention progression through the entire episode of carefor the patient.

In the literature, Dressendorfer and Brence note that muscle force couple imbalance is the primary impairment which leads to altered arthrokinematics and eventually SIS symptomology $[2,4]$. This was exactly the case in this patient. By addressing these muscular imbalances, proper scapular

Table 7. Interventions provided for each treatment sessions.

\begin{tabular}{|c|c|c|c|}
\hline Treatment Session & Intervention & Parameters & Rationale \\
\hline 1 & - $\quad$ Initial evaluation & 1 hour & Development of POC \\
\hline 2 & $\begin{array}{ll}\text { - } & \text { Soft tissue work } \\
\text { - } & \text { Robbery rows } \\
\text { - } & \text { Prone scapular depressions }\end{array}$ & $\begin{array}{l}\text { - } \quad 30 \text { mins } \\
\text { - } \quad 3 \text { sets, } 10 \text { reps, red resistance tubing } \\
\text { - } \quad 3 \text { sets, } 10 \text { reps }\end{array}$ & $\begin{array}{l}\text { - Assist with resolution of trigger } \\
\text { points } \\
\text { Increase strength of scapular } \\
\text { stabilizers to facilitate proper } \\
\text { scapulohumeral rhythm }\end{array}$ \\
\hline 3 & $\begin{array}{ll}\text { - } & \text { Sustained left shoulder stretching } \\
\text { - } & \text { Joint mobilizations } \\
\text { - } & \text { Robbery rows } \\
\text { - } & \text { Prone scapular depressions } \\
\text { - } & \text { Sitting scapular depressions }\end{array}$ & $\begin{array}{ll}- & 15 \text { mins } \\
\text { - } & 10 \text { mins } \\
\text { - } & 3 \text { sets, } 10 \text { reps, red resistance } \\
& \text { tubing } \\
\text { - } \quad & 3 \text { sets, } 10 \text { reps } \\
\text { - } & 3 \text { sets, } 10 \text { reps, green resistance } \\
& \text { tubing }\end{array}$ & $\begin{array}{l}\text { - Increase end joint ROM by } \\
\text { stretching posterior capsule } \\
\text { Facilitate proper movement } \\
\text { of humeral head within the } \\
\text { glenohumeral joint } \\
\text { Increase strength of scapular } \\
\text { stabilizers to facilitate proper } \\
\text { scapulohumeral rhythm }\end{array}$ \\
\hline 4 & $\begin{array}{ll}\text { - } & \text { Manual soft tissue work to the up- } \\
\text { - } & \text { Rer trap and infraspinatus } \\
\text { - } & \text { Prone scapular depressions } \\
\text { - } & \text { Sitting scapular depressions } \\
\text { - } & \text { Sidelying horizontal tabletop slides }\end{array}$ & $\begin{array}{ll}- & 25 \text { mins } \\
\text { - } & 3 \text { sets, } 10 \text { reps, red resistance } \\
& \text { tubing } \\
\text { - } & 3 \text { sets, } 10 \text { reps } \\
\text { - } & 3 \text { sets, } 10 \text { reps, green resistance } \\
& \text { tubing } \\
\text { - } & 3 \text { sets, } 10 \text { reps, } 2 \text {-pound dumbbell }\end{array}$ & $\begin{array}{l}\text { - Assist with resolution of trigger } \\
\text { points } \\
\text { Increase strength of scapular } \\
\text { stabilizers to facilitate proper } \\
\text { scapulohumeral rhythm }\end{array}$ \\
\hline 5 & $\begin{array}{ll}\text { - } & \text { Sustained left shoulder stretching } \\
\text { - } & \text { Joint mobilizations } \\
\text { - } & \text { Robbery Rows } \\
\text { - } & \text { Prone scapular depressions } \\
\text { - } & \text { Sitting scapular depressions } \\
\text { - } & \text { Sidelying horizontal tabletop slides } \\
\text { ER with resistance band at } 90^{\circ}\end{array}$ & $\begin{array}{l}\text { - } 15 \text { mins } \\
\text { - } \quad 10 \text { mins } \\
\text { - } 3 \text { sets, } 10 \text { reps, red resistance } \\
\text { tubing } \\
\text { - } \quad 3 \text { sets, } 10 \text { reps } \\
\text { - } \quad 3 \text { sets, } 10 \text { reps, red resistance band } \\
\text { - } \quad 3 \text { sets, } 10 \text { reps, } 2 \text {-pound dumbbell } \\
\text { - } 3 \text { sets, } 10 \text { reps, red resistance } \\
\text { tubing }\end{array}$ & $\begin{array}{l}\text { - Increase ROM and decrease } \\
\text { capsular tightness } \\
\text { Increase strength of scapular } \\
\text { stabilizers } \\
\text { Increase strength of rotator cuff } \\
\text { muscles to facilitate stabilization } \\
\text { of humeral head within the joint }\end{array}$ \\
\hline 6 & $\begin{array}{ll}\text { - } & \text { Manual soft tissue work to supra- } \\
\text { spinatus and infraspinatus } \\
\text { - } \quad \text { Right sidelying ER with towel } \\
\text { - } \quad \text { Prone scapular depressions } \\
\text { Tabletops }\end{array}$ & $\begin{array}{ll}- & 25 \text { mins } \\
\text { - } & 3 \text { sets, } 10 \text { reps, } 2 \text {-pound dumbbell } \\
\text { - } & 3 \text { sets, } 10 \text { reps } \\
\text { - } & 3 \text { sets, } 10 \text { reps, } 2 \text {-pound dumbbell }\end{array}$ & $\begin{array}{l}\text { Assist with resolution of trigger } \\
\text { points } \\
\text { Increase strength of rotator } \\
\text { cuff musculature to facilitate } \\
\text { increased stabilization of } \\
\text { the humeral head within the } \\
\text { shoulder capsule } \\
\text { Increase strength of scapular } \\
\text { stabilizers }\end{array}$ \\
\hline 7 & $\begin{array}{ll}\text { - } & \text { Manual soft tissue work to } \\
\text { - } & \text { Arpraspinatus and rhomboids } \\
\text { - } & \text { Robbery rows } \\
\text { - } & \text { Body blade } \\
\text { - } & \text { Right sidelying ER with towel } \\
\text { - } & \text { Tabletops } \\
\text { - } & \text { Prone 90-90 rows }\end{array}$ & $\begin{array}{l}\text { - } 20 \text { mins } \\
\text { - } 3 \text { sets, } 12 \text { reps, bodyweight } \\
3 \text { sets, } 12 \text { reps, green resistance } \\
\text { band } \\
\text { - } 3 \text { sets, } 30 \text { seconds per set, sagittal } \\
\text { and transverse plane } \\
\text { - } 3 \text { sets, } 12 \text { reps, } 2 \text {-pound dumbbell } \\
\text { - } 3 \text { sets, } 12 \text { reps, } 2 \text {-pound dumbbell } \\
\text { - } 3 \text { sets, } 12 \text { reps, } 4 \text {-pound dumbbell }\end{array}$ & $\begin{array}{l}\text { Assist with resolution of trigger } \\
\text { points } \\
\text { Increase strength of rotator } \\
\text { cuff musculature to facilitate } \\
\text { increased stabilization of } \\
\text { the humeral head within the } \\
\text { shoulder capsule } \\
\text { Increase strength of scapular } \\
\text { stabilizers }\end{array}$ \\
\hline
\end{tabular}


Zollinger et al, Physical Therapy and Rehabilitation 2018,

\section{Continuation of Table 7.}

\begin{tabular}{|c|c|c|c|}
\hline 8 & 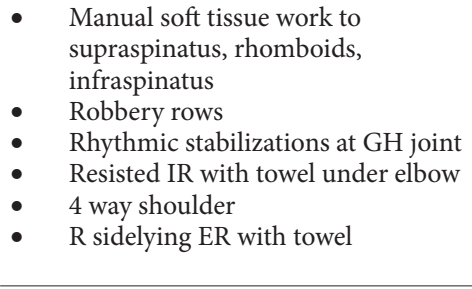 & $\begin{array}{l}\text { - } \quad 20 \text { mins } \\
\text { - } \quad \text { sets, } 12 \text { reps, green resistance } \\
\text { band } \\
3 \text { sets, } 30 \text { seconds, PT providing } \\
\text { perturbations } \\
\text { - } \quad 3 \text { sets, } 12 \text { reps, red resistance band } \\
3 \text { sets, } 12 \text { reps, green resistance } \\
\text { band } \\
\text { - } 3 \text { sets, } 12 \text { reps, 2-pound dumbbell }\end{array}$ & $\begin{array}{l}\text { - Assist with resolution of trigger } \\
\text { points } \\
\text { Increase strength of rotator } \\
\text { cuff musculature to facilitate } \\
\text { increased stabilization of } \\
\text { the humeral head within the } \\
\text { shoulder capsule } \\
\text { Increase strength of scapular } \\
\text { stabilizers }\end{array}$ \\
\hline 9 & $\begin{array}{ll}\text { - } & \text { Manual soft tissue work to } \\
\text { - } & \text { supraspinatus and infraspinatus } \\
\text { - } & \text { Right sidelying ER with towel } \\
\text { - } & \text { Tabletops } \\
\text { - } & \text { Robbery rows } \\
\text { - } & 4 \text { way shoulder } \\
\text { - } & \text { Prone } 90-90 \text { rows } \\
\text { - } & \text { Prone } 90-90 \text { ball flips }\end{array}$ & $\begin{array}{l}\text { - } \quad 10 \text { mins } \\
\text { - } \quad 10 \text { mins, inferior and posterior } \\
\text { - } \quad 3 \text { sets, } 12 \text { reps, 2-pound dumbbell } \\
\text { - } \quad 3 \text { sets, } 12 \text { reps, 2-pound dumbbell } \\
\text { - } \quad 3 \text { sets, } 12 \text { reps, green resistance } \\
\text { band } \\
\text { - } \quad 2 \text { sets, } 12 \text { reps, green resistance } \\
\text { band } \\
\text { - } \quad 3 \text { sets, } 12 \text { reps, } 4 \text {-pound dumbbell } \\
\text { cine ball } 30 \text { reps, 1.1-pound medi- }\end{array}$ & 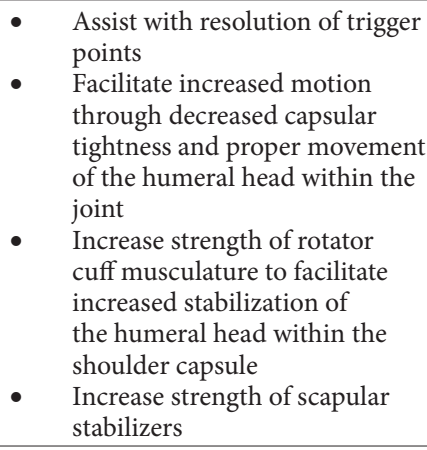 \\
\hline 10 & $\begin{array}{ll}\text { - } & \text { Manual soft tissue work } \\
\text { - } & \text { Humeral head joint mobilizations } \\
\text { - } & \text { Table tops } \\
\text { - } & \text { R sidelying ER with towel } \\
\text { - } & \text { Prone 90-90 Rows } \\
\text { - } & \text { Resisted IR with towel } \\
\text { - } & \text { Prone 90-90 ball flips }\end{array}$ & $\begin{array}{l}\text { - } 15 \text { mins } \\
\text { - } \quad 3 \text { mins } \\
3 \text { sets, } 12 \text { reps, green resistance } \\
\text { band } \\
\text { - } 3 \text { sets, } 12 \text { reps, } 2 \text {-pound dumbbell } \\
\text { - } 3 \text { sets, } 12 \text { reps, } 2 \text {-pound dumbbell } \\
\text { - } 3 \text { sets, } 12 \text { reps, } 4 \text {-pound dumbbell } \\
\text { - } 3 \text { sets, } 12 \text { reps, red resistance band } \\
3 \text { sets, } 30 \text { reps, } 1.1 \text {-pound } \\
\text { medicine ball }\end{array}$ & $\begin{array}{l}\text { Assist with resolution of trigger } \\
\text { points } \\
\text { Facilitate increased motion } \\
\text { through decreased capsular } \\
\text { tightness and proper movement } \\
\text { of the humeral head within the } \\
\text { joint } \\
\text { Increase strength of rotator } \\
\text { cuff musculature to facilitate } \\
\text { increased stabilization of } \\
\text { the humeral head within the } \\
\text { shoulder capsule } \\
\text { Increase strength of scapular } \\
\text { stabilizers }\end{array}$ \\
\hline 11 & $\begin{array}{ll}\text { - } & \text { Manual soft tissue work } \\
\text { - } & \text { Robbery rows } \\
\text { - } & \text { Standing 90-90 ball flips } \\
& \text { Standing 90-90 ER static hold with } \\
\text { - } & \text { Wallslides on forearms } \\
\text { - } & \text { Wall ball } \\
\text { - } & \text { Prone rows on Swiss ball }\end{array}$ & $\begin{array}{l}\text { - } \quad 10 \text { mins } \\
\text { - } 3 \text { sets, } 12 \text { reps, green resistance } \\
\text { band } \\
\text { - } 3 \text { sets, } 30 \text { reps, } 2.2 \text {-pound ball } \\
\text { - } 3 \text { sets, } 30 \text { seconds, red resistance } \\
\text { band } \\
\text { - } 3 \text { sets, } 12 \text { reps, red resistance band } \\
1 \text { set, } 1 \text { minute, in } 4 \text { different } \\
\text { positions, clockwise and counter } \\
\text { clockwise } \\
\text { - } 3 \text { sets, } 12 \text { reps, } 5 \text {-pound dumbbell } \\
\end{array}$ & $\begin{array}{l}\text { - Assist with resolution of trigger } \\
\text { points } \\
\text { Increase strength of rotator } \\
\text { cuff musculature to facilitate } \\
\text { increased stabilization of } \\
\text { the humeral head within the } \\
\text { shoulder capsule } \\
\text { Increase strength of scapular } \\
\text { stabilizers }\end{array}$ \\
\hline 12 & Shoulder assessment and re-testing & & \\
\hline HEP & $\begin{array}{ll}\text { - } & \text { Bilateral passive shoulder flexion } \\
\text { - } & \text { stretch } \\
\text { - } & \text { Push } \\
\text { - } & \text { Shrugs Plus } \\
\text { - } & \text { Doorway Pec stretch } \\
\text { - } & \text { Upper trap stretch } \\
\text { - } & \text { Sleeper stretch } \\
\text { - } & \text { Doorway ER stretch } \\
\text { - } & \text { Scapular depressions (seated and } \\
\text { - } & \text { prone) } \\
& 4 \text { way shoulder }\end{array}$ & $\begin{array}{l}\text { Pt was provided with resistance } \\
\text { bands allowing her to complete } \\
\text { HEP }\end{array}$ & \\
\hline
\end{tabular}

* Trigger points were treated via manual techniques including ischemic digital compression, massage, and/or soft tissue strumming techniques.

upward rotation (opposed to superior translation) and humeral head stabilization, without superior and anterior translation during movement, would theoretically be corrected $[2,4]$. To address these issues, the patient was instructed to begin with scapular stabilization exercises while allowing the irritation within the subacromial space to subside [8]. Through increasing 
Zollinger et al, Physical Therapy and Rehabilitation 2018,

scapular stabilization, muscle force couple imbalances would be addressed, leading to more normalized glenohumeral arthrokinematics. Considering the results of the manual muscle testing, middle and lower trapezius, rhomboideus, and serratus anterior muscle strengthening was prioritized over strengthening of the upper trapezius. A study by Cools et al. found that patients with SIS often displayed hyperactive upper trapezius musculature with associated hypoactive lower trapezius muscle function during shoulder abduction [9]. Furthermore, with external rotation of the glenohumeral joint, Cools et al. found decreased activity of the middle trapezius with increased activity of the upper trapezius, also leading to muscle force couple imbalance [9]. With these force couple imbalances and the upper trapezius reacting faster than the lower trapezius, altered arthrokinematics with superior translation of the scapula opposed to upward rotation is common [10].

Once the exacerbation of pain within the subacromial space was mitigated with positioning and scapular stabilization, the interventions progressed to strengthening and improving the endurance of the rotator cuff musculature [4]. The rotator cuff is responsible for maintaining a stabilizing force to the humeral head in the glenoid fossa during flexion and abduction movements of the shoulder [2]. With weakness of the rotator cuff musculature, the stabilizing force is diminished and may lead to symptoms of impingement secondary to increased humeral head translation [2]. As stated by Ellenbecker and Cools, the primary goal with interventions are to achieve high levels of activation while decreasing the amount of subacromial contact [4]. Repetitions for the exercises aimed to achieve muscle fatigue to promote endurance gains [4].

The goal of therapeutic exercise was to improve strength deficits found during manual muscle testing, restore proper arthrokinematics, and increase the scapular stability as noted with bilateral scapular dyskinesia via observation.

The three primary manual therapy techniques used with this patient were manual stretching, joint mobilizations, and soft tissue mobilization. In manual stretching, the patient's involved shoulder was moved to end range and held for 30 seconds with inferior and posterior joint oscillations performed between each stretch(See Table 7). The reasoning behind using manual stretching was primarily to increase the patient's pain free ROM. However, in a study done by Bang and Deyle, they found patients receiving manual therapy, in addition to a supervised exercise program, experienced overall increased functional activity when compared to the control group who performed only a supervised exercise program [11]. Additionally, the experimental group also had a statistically significant strength gain and decrease in pain [11]. The strength gains demonstrated in this study were primarily seen with shoulder abductors, external and internal rotators [11].

Joint mobilizations were utilized to address hypomobility of the glenohumeral joint capsule noted in the posterior and inferior directions of the involved shoulder. Grades II and III oscillations were performed for pain relief and to repetitively load the restricted aspects of the joint capsule. The primary purpose of utilizing joint oscillations was to decrease the capsular restriction, thus leading to increased joint ROM and proper arthrokinematics $[11,12]$. In addition to the study by Bang and Deyle, Kachingwe et al., found that in two experimental groups receiving manual therapy (joint mobilizations and joint mobilizations along with mobilizations with movement), a higher percent change in pain and function (although not statistically significant) in the manual therapy groups from baseline to discharge when compared to a control group completing only a supervised exercise program [12]. This improvement in pain was likely due to movement within the joint that activated mechanoreceptors, leading to an analgesic response prior to completing their supervised exercise program [12]. The improvement in joint arthrokinematics likely resulted from capsular stretching during the manual techniques [12].

After reviewing the findings from available current literature, each treatment session with the patient began with manual therapy. The manual therapy and soft tissue techniques included joint mobilizations, ischemic digital compression $[18,19]$, soft tissue massage, and/or soft tissue strumming [20] were performed with the primary goal of improving pain free ROM, decreasing capsular restrictions, and resolving taut bands and myofascial trigger points found within the surrounding musculature.

\section{Outcomes}

The results presented in Tables 1-4 demonstrate the success of the treatment in a variety of aspects. In considering the manual muscle testing results, the patient normalized strength tests (5/5 in all tested muscle groups) indicating return of normal strength bilaterally. The ROM measurements showed significant changes in all motions that were initially limited, except for flexion. The lack of gains with flexion will be detailed in the discussion section below. Upon initial examination, the patient presented with a QDASH score of 18. At the time of discharge, the patient had decreased that score to 5, representing a 13-point change, which meets the minimal detectable change of the QDASH [13]. Pain decreased to a subjective pain rating of $0 / 10$ at the end of the treatment sessions. Through completing the implemented treatment plan, the patient tested negative for all clinical special tests and was able to return to her normal activities of daily living. Additionally, the patient was able to return to all rock climbing activities pain free and left for another expedition in Canada following discharge from physical therapy. Finally, this case report demonstrates evidence that a patient with signs and symptoms of the functional classification of SIS is amenable to physical therapy treatment and patients with a functional classification of SIS may benefit and progress to return to all functional activities without surgical intervention. Thus, the success seen in this case report was secondary to the func- 
Zollinger et al, Physical Therapy and Rehabilitation 2018,

tional classification of SIS seen in this patient as opposed to a structural classification.

\section{Discussion}

The treatments performed in this case report were all based on current literature detailing etiology and treatment strategies for SIS. According to Escamilla, Hook, and Wilk, the primary focus of rehabilitation for SIS is to reduce mechanical stress that may be present on the rotator cuff tendon and to restore vascularity to the tendon that may be decreased secondary to a variety of different etiologies [14]. With this rehabilitation focus, goals should be established that focus on the restoration of full glenohumeral joint ROM and rotator cuff dynamic stability [14]. Progressive resistive exercises designed to restore strength and endurance of the rotator cuff and scapular stabilizing muscles while incorporating sport specific training and functional activities should be employed to assist in making a full recovery to functional activities [14]. As the results of this case report demonstrate, the patient successfully met these goals.

On initial evaluation and at discharge, the patient was apprehensive to a bilateral passive stretch of her shoulders in flexion near $150^{\circ}$ and did not feel comfortable with further motion. This discomfort represented an empty end feel of motion due to the inability to determine the causative factor of the decreased ROM. It was determined, after discussion with colleagues, the $150^{\circ}$ of flexion, bilaterally, represented the patient's normal functional AROM; not the normal $180^{\circ}$ as expected. This decreased ROM was most likely secondary to continuous rock-climbing activities which mandated stability of the shoulder girdle complex. Considering this caveat, the patient was able to demonstrate full ROM with all other motions of the glenohumeral joint passively, and also near full AROM in these other motions. Additionally, referring to Table 4, it should be noted that a manual muscle test for the upper trapezius was not performed at discharge. This decision was made for two primary reasons. First, literature supports that the upper trapezius is generally found to be hyperactive in SIS and contributes to scapular dyskinesia that is often present [2]. Second, the patient was fully strong without weakness initially and there was no evidence of that changing during the treatment. Hence, a retest was not necessary as a decrease in strength was not seen and/or anticipated.

Current literature supports the use of manual therapy in addition to a supervised therapeutic exercise program in treating functional SIS. This case supports and agrees with current literature. The application of manual therapy in addition to exercise demonstrated significant gains for the patient. Through the use of manual therapy, treatment addressed the restrictions that were present within the glenohumeral joint capsule in the posterior and inferior directions, allowed for soft tissue stretching, and, as hypothesized by Bang and Deyle, stimulated mechanoreceptors to allow a decrease in pain which likely led to an increased ability of the patient to complete therapeutic exercises [11]. The results of this case study add to and support current literature in its successful treatment of functional SIS by conservative measures utilizing manual therapy and supervised therapeutic exercise to prevent re-injury and a return to previously functional status. Future research should focus on the early address of functional SIS with conservative treatments and the use of directed joint mobilizations to enhance the rehabilitation outcomes of postsurgical patients with structural SIS.

\section{Limitations}

The primary limitation is that the results of this case report cannot be applied to the general population secondary to the results being from a single patient. While all interventions and treatments were based on current literature, the results achieved in this case report do not apply to all patients who suffer from SIS.

Another limitation was the activity level of the patient during the initial treatment sessions. Although being properly educated on her condition and exacerbating factors, the patient continued to live an active lifestyle which included repetitive overhead activities which may not have allowed the initial inflammation within the subacromial space to resolve.

After extensive patient education, the patient agreed to limit overhead activities to allow the inflammation to resolve and treatment to progress. The patient also was not interested in beginning a regimen of anti-inflammatory medications to assist in symptom resolution which may or may not have contributed to the overall success of the treatment plan.

\section{Conclusion}

The purpose of this case report was to describe an episode of care using a conservative approach to the treatment of functional SIS in a professional rock climber. For this patient, four of five established goals were achieved, and the patient was able to leave for another rock climbing expedition at the conclusion of therapy. With current research as the guide for treatment, the patient was able to achieve gains in ROM of the glenohumeral joint, strength of scapular stabilizers and surrounding shoulder musculature, endurance of shoulder musculature, and improve shoulder function as well as a decrease in pain with specific positioning of the involved shoulder. In conclusion, this case report demonstrates that a professional athlete suffering from a functional classification of SIS can experience a full recovery with conservative treatment, avoid the progression to a chronic impairment, and perhaps skirt a surgical intervention decision to resolve the condition.

\section{List of abbreviations}

SIS: Subacromial impingement syndrome

QDASH: Quick Disabilities of Arm, Shoulder, and Hand

ROM: Range of motion

AROM: Active range of motion 
Zollinger et al, Physical Therapy and Rehabilitation 2018,

PROM: Passive range of motion

EMG: Electromyography

\section{Competing interests}

The authors declare that they have no competing interests.

Authors' contributions

\begin{tabular}{|l|c|c|c|}
\hline Authors' contributions & CZ & AU & DG \\
\hline Research concept and design & $\checkmark$ & -- & -- \\
\hline Collection and/or assembly of data & $\checkmark$ & -- & -- \\
\hline Data analysis and interpretation & $\checkmark$ & $\checkmark$ & $\checkmark$ \\
\hline Writing the article & $\checkmark$ & $\checkmark$ & $\checkmark$ \\
\hline Critical revision of the article & $\checkmark$ & $\checkmark$ & $\checkmark$ \\
\hline Final approval of article & $\checkmark$ & $\checkmark$ & $\checkmark$ \\
\hline Statistical analysis & -- & -- & -- \\
\hline
\end{tabular}

Acknowledgements

The authors would like to thank Idaho State University

for supporting this project. Special thanks also to

Tori Taylor, PT, DPT, for her mentorship.

\section{Publication history}

Editor: Mohammad H. Hadadzadeh, Wheeling Jesuit University, USA.

Received: 10-Jan-2018 Final Revised: 19-Mar-2018

Accepted: 29-Mar-2018 Published: 15-Apr-2018

\section{References}

1. Dressendorfer R. Subacromial impingement syndrome. Cinahl Rehabilitation Guide. 2017.

2. Page $P$. Shoulder muscle imbalance and subacromial impingement syndrome in overhead athletes. Int J Sports Phys Ther. 2011; 6:51-8. PubMed Abstract | PubMed FullText

3. Schub T and Kornusky J. Subacromial impingement syndrome. Cinahl Nursing Guide 2016.

4. Ellenbecker TS and Cools A. Rehabilitation of shoulder impingement syndrome and rotator cuff injuries: an evidence-based review. $\mathrm{Br} J$ Sports Med. 2010; 44:319-27. | Article | PubMed

5. Brence J. Clustering signs and symptoms to diagnose rotator cuff pathology. Sportex Medicine. 2015; 63: 32-33.

6. Hughes PC, Taylor NF and Green RA. Most clinical tests cannot accurately diagnose rotator cuff pathology: a systematic review. Aust J Physiother. 2008; 54:159-70. | Article | PubMed

7. Kimball KM. Shoulder, common shoulder procedures. 2017. | Article

8. Baskurt Z, Baskurt F, Gelecek N and Ozkan MH. The effectiveness of scapular stabilization exercise in the patients with subacromial impingement syndrome. J Back Musculoskelet Rehabil. 2011; 24:173-9. | Article I PubMed

9. Cools AM, Declercq GA, Cambier DC, Mahieu NN and Witvrouw EE. Trapezius activity and intramuscular balance during isokinetic exercise in overhead athletes with impingement symptoms. Scand J Med Sci Sports. 2007; 17:25-33. | Article | PubMed

10. Cools AM, Witvrouw EE, Declercq GA, Danneels LA and Cambier DC. Scapular muscle recruitment patterns: trapezius muscle latency with and without impingement symptoms. Am J Sports Med. 2003; 31:542-9. | Article | PubMed

11. Bang MD and Deyle GD. Comparison of supervised exercise with and without manual physical therapy for patients with shoulder impingement syndrome. J Orthop Sports Phys Ther. 2000; 30:126-37. | Article | PubMed

12. Kachingwe AF, Phillips B, Sletten E and Plunkett SW. Comparison of manual therapy techniques with therapeutic exercise in the treatment of shoulder impingement: a randomized controlled pilot clinical trial. J Man Manip Ther. 2008; 16:238-47. | Article | PubMed Abstract | PubMed FullText

13. Quick Disabilities of Arm, Shoulder, and Hand. 2017. I Website

14. Escamilla RF, Hooks TR and Wilk KE. Optimal management of shoulder impingement syndrome. Open Access J Sports Med. 2014; 5:13-24. | Article | PubMed Abstract | PubMed FullText

15. Gajdosik RL and Bohannon RW. Clinical measurement of range of motion. Review of goniometry emphasizing reliability and validity. Phys Ther. 1987; 67:1867-72. | PubMed

16. Hislop HJ, Avers D and Brown M. Daniels and Worthingham's muscle testing: Techniques of manual examination and performance testing. In Relevance and Limitations of Manual Muscle Testing. $\mathbf{9}^{\text {th }}$ ed. St. Louis, MI: Elsevier Saunders. 2014; 12-18.

17. Dessaur WA and Magarey ME. Diagnostic accuracy of clinical tests for superior labral anterior posterior lesions: a systematic review. J Orthop Sports Phys Ther. 2008; 38:341-52. | Article | PubMed

18. Gemmell $\mathrm{H}$ and Allen A. Relative immediate effect of ischaemic compression and activator trigger point therapy on active upper trapezius trigger points: A randomizedtrial. Clinical Chiropractic. 2008;11:175-181. | Article

19. Moraska AF, Hickner RC, Kohrt WM and Brewer A. Changes in blood flow and cellular metabolism at a myofascial trigger point with trigger point release (ischemic compression): a proof-of-principle pilot study. Arch Phys Med Rehabil. 2013; 94:196-200. | Article | PubMed Abstract | PubMed FullText

20. Wong CK, Coleman D, diPersia V, Song J and Wright D. The effects of manual treatment on rounded-shoulder posture, and associated muscle strength. J Bodyw Mov Ther. 2010; 14:326-33. | Article | PubMed

\section{Citation:}

Zollinger C, Urfer A and Gerber D. Physical therapy management of an elite rock climber with subacromial impingement syndrome (SIS). Phys Ther Rehabil. 2018; 5:4. http://dx.doi.org/10.7243/2055-2386-5-4 